\title{
PENGARUH DISPLAY PRODUK DAN PROMOSI PENJUALAN TERHADAP PEMBELIAN IMPULSIF DI INDOMARET JL. SETIA BUDI NO. 20 MEDAN
}

\author{
Andre Arnanda ${ }^{1)}, \&$ T. Teviana ${ }^{2 *}$ \\ 1) Fakultas Ekonomi, Universitas Negeri Medan \\ 2) Fakultas Ekonomi, Universitas Negeri Medan \\ E-mail : teviana3004@gmail.com
}

\begin{abstract}
Abstrak
Penelitian bertujuan untuk mengetahui pengaruh Display Produk dan Promosi Penjualan Terhadap Pembelian Impulsif di Indomaret Jl.Setia Budi No. 20 Medan. Penelitian dilaksanakan di Indomaret Jl. Setia Budi No. 20 Medan. Sampel penelitian berjumlah 100 responden. Pengambilan sampel menggunakan rumus slovin.Teknik pengumpulan data yang digunakan adalah kuesioner yang pengukuranny amenggunakan skala Interval dan diolah secarastatistik menggunakan metode analisis regresi berganda dengan persamaan $\mathrm{Y}=\mathrm{a}+\mathrm{b}_{1} \mathrm{X}_{1}+\mathrm{b}_{2} \mathrm{X}_{2}+\mathrm{e}$ melalui program IBM SPSS Statistics 23. Hasil penelitian menunjukkan variabel Display Produk $\left(\mathrm{X}_{1}\right)$ dan Promosi Penjualan $\left(\mathrm{X}_{2}\right)$ secara simultan berpengaruh signifikan terhadap Pembelian Impulsif $(\mathrm{Y})$. Dengan demikian dapat disimpulkan display produk dan promosi penjualan mempunyai pengaruh positif dan signifikan terhadap pembelian pembelian impulsif di Indomaret Jl. Setia Budi No. 20 Medan.
\end{abstract}

\section{Kata kunci: Display Produk, Promosi Penjualan, Pembelian Impuilsif}

The study aims to determine the effect of Product Display and Sales Promotion on Impulsive Purchase at IndomaretJl.Setia Budi No. 20 Medan.The study was conducted at Indomaret Jl. Setia Budi No. 20 Medan. The sample of research is 100 respondents. Sampling using the slovin formula. Data collection techniques used were questionnaires that measured using Interval scale and processed statistically using multiple regression analysis method with the equation $Y=a+b 1 X 1+b 2 X 2+e$ through IBM SPSS Statistics 23 program. The results showed that product display (X1) and sales promotion (X2) variables simultaneously have significant effect on impulsive purchase (Y).

Thus it can be concluded product display and sales promotion has a positive and significant influence on impulsive purchases on Jl. Setia Budi No. 20 Medan, simultaneously or partially.

Keywords: Product Display, Sales Promotion, Impuilsive Purchase

\section{PENDAHULUAN}

Fenomena

perkembangan

usaha atau bisnis di Indonesia dewasa ini telah mengalami peningkatan yang cukup pesat. Hampir tidak ditemukan sebuah bisnis yang dapat berjalan sendiri tanpa mengalami persaingan.
Bahkan, pada beberapa bidang bisnis, terjadi persaingan yang sangat ketat, sehingga pemimpin pasar atau market leader pada industri tersebut senantiasa berganti-ganti setiap tahunnya. Bisnis ritel juga mengalami hal yang sama. Berbagai jenis format 
ritel serta jenisnya terus mengalami perkembangan. Mulai dari Hypermarket, Supermarket, Minimarket hingga toko kelontong yang tergolong dalam traditional market. Hal ini sebagai akibat dari adanya perkembangan usaha manufaktur dan peluang pasar yang cukup terbuka, maupun upaya pemerintah untuk mendorong perkembangan bisnis ritel.

Menurut Asosiasi Perusahaan Ritel Indonesia (Aprindo), pertumbuhan bisnis ritel di Indonesia antara $10 \%-15 \%$ per tahun. Penjualan ritel pada tahun 2006 masih sebesar Rp 49 triliun, dan melesat hingga mencapai Rp 120 triliun pada tahun 2011. Pada tahun 2012, pertumbuhan ritel diperkirakan masih sama, yaitu $10 \%-15 \%$, atau mencapai $\mathrm{Rp} 138$ triliun. Jumlah pendapatan terbesar merupakan kontribusi dari hipermarket kemudian disusul oleh minimarket dan supermarket (www.marketing.co.id).

Bisnis ritel sering kali dilihat sebagai cermin perekonomian suatu negara,apalagi pendapatan perkapita yang terus mengalami pertumbuhan,menjadi peluang dalam bisnis ritel.sehingga para peritel berlomba-lomba untuk meningkatkan omset penjualan disetiap periodenya. Omset penjualan didapat dari kegiatan belanja atau pembelian yang dilakukan oleh konsumen dan juga pelanggan dalam toko tersebut.

Peningkatan

pendapatan

konsumen meyebabkan kebutuhan konsumen ikut meningkat, dan kebutuhan yang terus-menerus meningkat meyebabkan tingkat belanja konsumen ikut meningkat.pada saat ini dalam perilaku pembelian telah terjadi pergeseran, dimana perilaku orang yang berbelanja dengan terencana menjadi tidak terencana. Orang yang tidak terencana berpikir pendek dan mencari serba instan serta mencari produk yang bisa memberi keuntungan jangka pendek dan panjang.

Hal ini mendorong pelanggan bertindak karena daya tarik atas sentimen atau gairah tertentu. Rook dan Fisher (2003), mendefinisikan impulse buying sebagai kecenderungan konsumen untuk membeli secara spontan, sesuai dengan suasana hati. Konsumen yang melakukan impulse buying tidak berpikir untuk membeli produk atau merek tertentu. Mereka langsung melakukan pembelian karena ketertarikan pada merek atau produk saat itu.

Pembelian impulsif (impulsive buying) terjadi ketika konsumen melihat produk atau merek tertentu, kemudian konsumen menjadi tertarik untuk mendapatkannya,biasanya karena adanya rangsangan yang menarik dari toko tersebut (Utami,2010:51).

Menurut Sopiah dan Syihabidhin (2008:238) "Display produk adalah usaha yang dilakukan untuk menata barang yang mengarahkan pembeli agar tertarik untuk melihat dan memutuskan untuk membelinya".

Dalam menarik konsumen untuk melakukan pembelian impulsif, perusahaan harus mampu menerapkan konsep pemasaran yang tepat sesuai dengan kondisi pasar sasaran.Konsep pemasaran yang tepat tentunya diharapkan mampu memenangkan hati konsumen dan mencapai keunggulan kompetitif dalam 
persaingan.Display produk merupakan salah satu konsep pemasaran yang dianggap penting karena mampu menarik minat beli konsumen. Dengan adanya display atau penataan produk yang menarik, konsumen akan tertarik dengan produk yang ditawarkan. Display produk akan merangsang rasa penasaran konsumen untuk menuju produk yang telah ditata sedemikian menarik, kemudian timbul rasa ingin membeli produk tersebut walaupun pada awalnya produk tersebut tidak termasuk dalam rencana pembelian.

Foster (2003:65) menyatakan bahwa kegiatan promosi berkaitan dengan seluruh kegiatan yang dilakukan perushaan dalam rangka mengomunikasikan kebaikan produknya dan membujuk konsumen untuk membeli produk tersebut. Sumarwan (2011:117) mengemukakan bahwa kegiatan promosi melalui potongan harga,diskon,paket harga serta adanya pemberian kupon mempengaruhi pembelian impulsif.

Promosi penjualan merupakan salah satu elemen dari marketing mix menjadi sangat penting. Dengan kata lain promosi penjualan mempunyai dampak terhadap penjualan. Ini karena trend perilaku pembelian kosumen yang sudah mengalami perubahan. Pertama, sensitif terhadap harga namun tetap mementingkan kualitas. Kedua, tidak menyukai suatu kelebihan yang sifatnya sama. Mereka ingin sesuatu yang lebih baik dan berbeda.

Tujuan dari promosi penjulan ini tentunya meningkatkan volume penjualan jangka pendek untuk perusahaan dengan menciptakan tampilan dan aktivitas yang menarik dan menimbulkan impulse buying didalam toko. Keuntungan lainnya yang bersifat jangka panjang adalah mendorong prilaku seseorang untuk mencoba suatu produk atau jasa untuk membuat konsumen menjadi pelanggan bagi perusahaan (Cummins dan Mullin,2004:17).

PT. Indomarco Prismatama Tbk. Adalah perusahaan ritel yang mempersilahkan pengunjung untuk melayani dirinya sendiri dalam mencari kebutuhan seperti perlengkapan sehari-hari, perlengkapan perawatan tubuh dan lain-lain. Didukung oleh jaringan pemasok lokal dan internasional terpercaya, gerai dengan visual menarik, berkualitas dan modern, memberikan kenyamanan berbelanja dan menyenangkan akan menjadikan indomaret sebagai pilihan utama bagi kelas menengah Indonesia yang tengah tumbuh pesat.

Indomaret berusaha untuk memenuhi kebutuhan dan keinginan para pelanggan. Untuk itulah Indomaret sebaik mungkin untuk menciptakan suasana yang nyaman agar konsumen tertarik untuk berbelanja di Indomaret. banyak cara yang dilakukan untuk mempertahankan pelanggannya antara lain dengan display produk yang menarik dan bersih agar konsumen yang berbelanja mendapatkan kenyamanan saat berkunjung, sehingga Indomaret menjadi salah satu alternatif pilihan masyarakat di kota Medan dalam berbelanja. Indomaret rutin melakukan promosi penjualan misalnya dalam merayakan tahun baru, tahun baru cina, hari valentine, bulan ramadhan, dan event-event lainnya dalam bentuk diskon, 
potongan harga, harga spesial atau lainnya.

\section{KAJIAN PUSTAKA \\ Pembelian Impulsif}

Pembelian impulsif adalah pembelian tidak terencana, disebabkan oleh ekspose dari stimulus dan diputuskan langsung di lokasi belanja. Jadi pembelian impulsif merupakan keputusan pembelian secara langsung dan tidak direncanakan, ketika melihat barangbarang yang menarik sehingga mendorong sesorang tersebut untuk melakukan pembelian pada saat berada di dalam toko.

\section{Display Produk}

Menurut Alma (2007:189) mendefinisikan display sebagai usaha mendorong perhatian dan minat konsumen pada toko atau barang dan mendorong keinginan membeli melalui daya tarik penglihatan langsung (direct visual appeal).

\section{Promosi Penjualan}

Kotler dan Armstrong (2008:204) juga menjelaskan definisi dari promosi penjualan, promosi penjualan adalah insentif jangka pendek untuk mendorong pembelian atau penjualan sebuah produk atau jasa.

\section{METODE PENELITIAN}

Lokasi penelitian bertempat di Indomaret Jl. Setia Budi No.20 Medan. Pada penelitian ini, populasi yang diambil adalah konsumen yang telah berbelanja produk di Indomaret Jl. Setia Budi No.20 Medan.Berdasarkan hasil pra survey yang dilakukan peneliti menyatakan bahwa rata rata konsumen yang melakukan membeli pada Indomaret Jl. Setia Budi No.20 Medan adalah sebanyak 70 orang per harinya. Jumlah konsumen dalam sebulan adalah 2.100 orang. Berdasarkan data kunjungan konsumen Indomaret $\mathrm{Jl}$. Setia Budi No, 20 Medan, diperoleh jumlah rata-rata konsumen yang berbelanja per harinya 100 orang. Teknik pengambilan sampel yang digunakan adalah Purposif Sampling yaitu teknik penentuan sampel berdasarkan kejadian kebetulan, artinya siapapun yang secara kebetulan bertemu dengan peneliti dengan kriteria sebagai pengunjung di lokasi penelitian dapat digunakan sebagai sampel dalam penelitian ini. Analisis regresi linier berganda ditujukan untuk menentukan hubungan liniar antara beberapa variabel bebas yang biasa disebut $\mathrm{X} 1, \mathrm{X} 2, \ldots \mathrm{Xn}$. dan seterusnya dengan variabel terikat yang disebut $\mathrm{Y}$. Uji statistik t pada dasarnya menunjukkan seberapa jauh pengaruh satu variabel independen secara individual dalam menerangkan variabel dependen. Hipotesis nol (H0) yang hendak diuji adalah apakah suatu parameter $(\beta 1)$ sama dengan nol, atau $\mathrm{H} 0: \beta 1=0$ yang artinya adalah variabel tersebut merupakan penjelasan yang signifikan terhadap variabel dependen. Uji $\mathrm{F}$ dimaksud kan untuk menguji ada tidaknya pengaruh variabel independen secara bersama-sama terhadap variabel dependen atau menguji tingkat keberartian hubungan seluruh koefisien regresi variabel independen terhadap variabel dependen.

\section{HASIL DAN PEMBAHASAN Hasil Penelitian}

Dari hasil pengelohan data, maka dapat dibuat persamaan regresinya. Persamaan regresi tersebut adalah : Y 
$=9.816+0,350 \times 1+0,349 \times 2+$ 3,390

a. Konstanta sebesar 9,816 dapat diartikan bahwa pembelian impulsif akan bernilsi 9,816 pada saat display produk dan promosi penjualan bernilai nol (tidak ada)

b. Koefisien regresi X1 sebesar 0,350 menyatakan bahwa kenaikan satu satuan Display Produk akan meningkatkan Pembelian Impulsif sebesar 0,350 .

c. Koefisien regresi X2 sebesar 0,349 menyatakan bahwa kenaikan satu satuan Promosi Penjualan akan meningkatkan Pembelian Impulsif sebesar 0,349 .

Uji hipotesis menggunakan nilai $\mathrm{F}$, yang diperoleh diperoleh dari hasil perhitungan adalah sebesar 12,322. Sedangkan angka Ftabel dihitung dengan ketentuan yaitu taraf signifikansi $95 \%$ dan alpha 55, serta derajat kebebasan (dk) dengan ketentuan $\mathrm{n}-2=100-2=$ 98. Dengan ketentuan tersebut diperoleh angka Ftabel sebesar 2,36. Dengan demikian diperoleh nilai Fhitung $=12,322>$ Ftabel $=2,36$. Karena Fhitung $>$ Ftabel, maka Ho ditolak dan $\mathrm{Ha}$ diterima, sehingga dapat disimpulkan bahwa secara simultan variabel bebas display produk dan promosi panjualan terhadap variabel terikat pembelian impulsif.

Uji $\mathrm{t}$ dilakukan untuk mengetahui besarnya pengeruh display produk dan promosi penjualan terhadap pembelian impulsif secara parsial. Pengaruh dapat dilihat dari nilai thitung. Berdasarkan tabel diperoleh hasil sebagai berikut :
1. Variabel display produk memiliki thitung $>$ ttabel yaitu sebesar 3.470> 1,660 dan taraf signifikansi sebesar $0,001<0,01$ sehingga dapat disimpulkan bahwa variabel display produk berpengaruh positif dan signifikan secara parsial terhadap pembelian impulsif.

2. Variabel promosi penjualan memiliki thitung $>$ tabel yaitu sebesar 3.079> 1,660 dan taraf signifikan sebesar $0,003<0,01$ sehingga dapat disimpulkan bahwa variabel promosi penjualan berpengaruh positif dan signifikan secara parsial terhadap pembelian impulsif.

Nilai koefisien determinasi $\mathrm{R}$ square sebesar 0,203. Nilai $\mathrm{R}$ square menunjukkan bahwa variabel independen yaitu variabel display produk dan promosi penjualan mampu menjelaskan variabel dependen yaitu pembelian impulsif sebesar 0,203 (20,3\%) dan sisanya 79,7 dipengaruhi oleh faktor - faktor lain yang tidak dibahas dalam penelitian ini.

\section{Pembahasan}

Setiap perusahaan mempunyai strategi pemasaraannya masingmasing.Strategi pemasaran ini dijalankan oleh setiap perusahaan agar perusahaan tersebut dapat bertahan dan bersaing. Salah satu strategi pemasaran yang dilakukan perusahaan yaitu dengan memberikan display produk yang menarik.

Produk yang sudah direncanakan dengan baik serta telah ditentukan harga jualnya secara tepat, belum tentu menjamin keberhasilan pemasaran terhadap produk tersebut. Hal ini disebabkan karena apabila 
produk sudah bagus dengan harga yang bagus tidak dapat dikenal oleh konsumen, maka produk tersebut tidak akan berhasil dipasarkan.

Data dalam penelitian ini diperoleh dengan cara menyebarkan kuesioner kepada konsumen yang berbelanja di Indomaret. penelitian ini bertujuan untuk melihat apakah terdapat pengaruh display produk dan promosi penjualan terhadap pembelian impulsif di Indomaret.

\section{SIMPULAN}

Setelah dilakukan uji hipotesis secara parsial variabel Display Produk (X1) berpengaruh positif dan signifikan (penataan bagian depan, penataan bagian dalam, penataan bagian luar) secara bersama-sama terhadap pembelian impulsif. Setelah dilakukan uji hipotesis secara parsial variabel Promosi Penjualan (X2) berpengaruh positif dan signifikan (bonus, pembelian dengan pembelian, diskon harga) secara bersama-sama terhadap pembelian impulsif. Setelah dilakukan uji hipotesis secara simultan variabel Display Produk dan Promosi berpengaruh positif dan signifikan terhadap Pembelian Impulsif.

\section{DAFTAR PUSTAKA}

Alma,Buchari.(2007).Manajemen Pemasaran dan Pemasaran Jasa. Bandung:Alfabeta.

Cummins, Julian dan Mullin, Roddy . 2004. Sales Promotion . Jakarta.PPM.

Foster, B. 2003. Manajemen Ritel. Bandung : Alfabeta

Kotler. Philip.2008.Dasar-Dasar Pemasaran.Edisi Bahasa Indonesia, Jakarta. Penerbit PT. Prehallindo.
Rook, D. W. \& Fisher, R.J. (2003). Normative Influences on Impulse Buying Behavior. The Journal of Consumer Research, Vol.22, No.3, 305313.

Utami, Christina Whidya. (2006). Manajemen Ritel, Strategi dan Implementasi Operaional Bisnis Ritel. Penerbit Salemba Empat, Jakarta

Sopiah dan Syahibudin. 2008, Manajemen Bisnis Ritel, Jakarta: Andi.

Sumarwan, Ujang, 2011, Perilaku Konsumen: Teori dan Penerapannya dalam Pemasaran, Ghalia Indonesia, Jakarta 